\title{
Adaptation of Three Different BLRI Strain (O, A, Asia 1) of Foot and Mouth Disease Virus Serotypes in Baby Hamster Kidney-21 Cell Line
}

\author{
Mohammad Showkat Mahmud*, Eusha Islam, Mohammed Abdus Samad, Md. Rezaul Karim, \\ Amal Kumar Saha, Md. Giasuddin
}

Research on FMD and PPR in Bangladesh, Animal Health Research Division, Bangladesh Livestock Research Institute, Bangladesh

Copyright(C2017 by authors, all rights reserved. Authors agree that this article remains permanently open access under the terms of the Creative Commons Attribution License 4.0 International License

\begin{abstract}
Baby Hamster Kidney-21(BHK-21) cells are the most commonly used cell for viral seed preparation and vaccine production. The aim of the present study was to adapt BLRI three different field isolates of foot and mouth disease virus (FMDV) serotypes (O, A, Asia 1) into baby hamster kidney-21 cell line for FMD trivalent master seed preparation. For this, samples were collected from the tongue epithelium, saliva, milk and inter digital tissues of the suspected animals from different districts of Bangladesh during the year 2011-2014. All samples were subjected to RNA extraction and RT-PCR for detection and serotyping of FMDV. BHK-21 cell subculture was done from a previously cultured flask containing BHK-21 cells. Prepared inocula (positive for serotype O, A, Asia 1) were inoculated into BHK-21 cell culture and cytopathic effects (CPE) were observed in BHK-21 cell line characterized by rounding and flattening of the cells, multinucleated giant cells formation, breaking down of the intracellular bridges and finally cell death indicated the presence of FMDV. Adaptation of the virus into baby hamster kidney-21 cell line was confirmed by detection of viral infection in infected cells by RT-PCR with serotype specific primers. The cell adapted foot and mouth disease virus in the present study provides a scope to undertake further research on foot and mouth disease virus in Bangladesh towards development of trivalent FMD vaccine for use in the country.
\end{abstract}

Keywords Foot-and-mouth Disease Virus, Cell Culture Adaptation, Baby Hamster Kidney-21 Cell Line, Reverse Transcription Polymerase Chain Reaction, Vaccine

\section{Introduction}

Foot and mouth disease (FMD) is considered a highly infectious disease of cattle, sheep, goats, and pigs. It also affects wild animals such as buffaloes and deer [1, 2]. It is characterized by rise in body temperature with saliva drooling from its mouth due to vesicular lesions on the tongue, gums, cheeks, and hard palate. The sick animals also show vesicular lesions in the cleft of feet, at their coronary bands and on teats of the milking animals. The vesicles soon rupture to form ulcerative lesions. There is a significant reduction in milk production, working efficiency and weight gain and abortions in infected animals. There is 100\% morbidity in susceptible animal population and negligible mortality in adults. However, high mortality in a young animal is due to the virus-induced necrotic lesions and myocardial degeneration $[3,4]$. Annual loss due to FMD in Bangladesh has been estimated at about US\$62 million [5].

The etiologic agent of the disease is the FMD virus which has seven serotypes have been recognized including $\mathrm{O}, \mathrm{A}, \mathrm{C}$, SAT-1, SAT-2, SAT-3, and Asia 1 [2]. FMDV serotype O, A and Asia-1 are the currently circulating FMDV in Bangladesh as revealed by RT-PCR [6]. Infection with one serotype does not confer immunity against another [7].

The control of FMD by animal vaccination was effective in limiting the spread of FMD [8]. Such control is dependent on the potency, efficacy, and specificity of the produced vaccine which is related directly on the infectivity and antigenicity of the vaccinal FMDV serotypes used in the vaccine. FMDV grow well on baby hamster kidney (BHK)-21 cell line enabling large-scale production of antigen with good antigenicity. However, the cell culture system is laborious, time-consuming, and relatively low sensitive. It also requires careful handling of samples and a good biosafety measures. It will help for the selection of vaccination, and strategies for the control of FMD in Bangladesh to improve the economy of farmers.

\section{Materials and Methods}

\subsection{Location and Period of Study}

The study was carried out in Foot and Mouth Disease 
research laboratory at Bangladesh Livestock Research Institute (BLRI), Savar, Dhaka during the year 2014-2016.

\subsection{Sample Collection}

Samples were collected from the tongue epithelium, saliva and inter digital tissue of the suspected animals from Savar, Joydevpur, Munshiganj, Kaliganj, Kapashia, Sirajganj, Kamrangichar, Kurigram, Rajshahi, Dinajpur, Tangail, Gaibandha, Nilphamari, Chittagong, Comilla District of Bangladesh during the year 2011- 2014. Samples were immediately transported with medium containing equal volumes of glycerol and phosphate-buffered saline $(\mathrm{pH}$ 7.2-7.6) and $2 \%$ antibiotic-antimycotic to the laboratory on ice.

\subsection{Inoculum Preparation, RNA Extraction and Sterility Test}

Piece of the epithelial tissue was removed from the glycerol buffer, blotted dry on absorbent paper to reduce the glycerol content. Approximately 1-2 gm tissue was weighted by an electric balance and homogenized by grinding with sterilized mortar and pestle. 20\% suspension was prepared by adding phosphate buffer saline. The suspension of each of the samples was then centrifuged at 3,000 rpm for 10 minutes maintaining temperature at $4^{\circ} \mathrm{C}$. The supernatant of each of the samples were taken for further processing according to OIE manual. For the sterility test, $1 \mathrm{ml}$ antibiotic-antimycotic solution 100X (Sigma, Germany) was added with appropriate amount to destroy bacterial and fungal contaminants. $50 \mu \mathrm{l}$ of inoculums was inoculated into nutrient and blood agar (Oxoid, UK) media to identify the presence of any type of bacterial contamination. RNA extraction was carried out from FMD inoculums by using the QIAamp ${ }^{\circledR}$ Viral RNA kit (Qiagen, Germany) according to the manufacture's protocol.

\subsection{Conventional Reverse Transcription Polymerase Chain Reaction (RT-PCR)}

The target in the genome was amplified by one step RT-PCR using the FMD universal and serotype specific primer $[9,10,11]$.The amplification was performed on a thermal cycler with one step RT-PCR kit (Qiagen, Germany) with one cycle of reverse transcription conditions of $50{ }^{\circ} \mathrm{C}$ for $30 \mathrm{~min}$ and $95^{\circ} \mathrm{C}$ for $10 \mathrm{~min}$ and followed by 30 cycles of $94{ }^{\circ} \mathrm{C}$ for $1 \mathrm{~min}, 55^{\circ} \mathrm{C}$ for $1 \mathrm{sec}$ (type A), $55^{\circ} \mathrm{C}$ for $30 \mathrm{sec}$ (type $\mathrm{O}$ ) and $72{ }^{\circ} \mathrm{C}$ for $1 \mathrm{~min}$ and finally one cycle of final extension of $72^{\circ} \mathrm{C}$ for $10 \mathrm{~min}$. After PCR, the amplified products were visualized by agarose gel electrophoresis using $2 \%$ agarose gel containing $0.6 \mathrm{mg} / \mathrm{ml}$ ethidium bromide at $100 \mathrm{~V}$ in $1 \mathrm{X}$ tris borate EDTA (TBE) buffer. At the end of electrophoresis, the gel was documented on a UV transilluminator (AlphaImager®Mini System, USA).

\subsection{Subculture of BHK-21 Cell}

All the media and reagents were brought to room temperature before use. The growth media containing 8-10\% fetal calf serum was removed from the flask. Then the monolayer cells were washed with sterile $1 \mathrm{X}$ PBS for 3 times. $0.5 \mathrm{ml}$ of trypsin was added into the flask and gentle tapping to detach the cells. The flask was left in the incubator for $2-3$ mins and observed under microscope. About $0.5 \mathrm{ml}$ growth media was added to the flask. Cell aggregation was broken by pipetting and depipetting. $5-7 \mathrm{ml}$ of media containing cell was poured into $25 \mathrm{~cm}^{2}$ flask. The flask was allowed to incubate at $37^{\circ} \mathrm{C}$ for $24 \mathrm{~h}$.

\subsection{Adaptation of FMDV in BHK-21 Cell Line}

A flask containing $70-80 \%$ completed cell monolayer was selected for giving infection. Then the monolayer cells were washed with sterile $1 \mathrm{X}$ PBS for $2-3$ times. $0.5 \mathrm{ml}$ virus suspension was added into $25 \mathrm{~cm}^{2}$ flask. The flask was incubated at $37^{\circ} \mathrm{C}$ for $45-60$ minutes for the establishment of better interaction between cell and virus. Finally, $7-10 \mathrm{ml}$ of the maintenance medium containing $2 \%$ fetal calf serum was added in the flask. Virus infected monolayer was incubated at $37^{\circ} \mathrm{C}$ and the cells were examined twice daily under microscope until show characteristic cytopathic effect (CPE) by FMDV. As control un-inoculated healthy monolayer was maintained. After completion of CPE, infected cell culture flask along with control cell monolayer were stored at $-20^{\circ} \mathrm{C}$. The cell culture supernatant was harvested by repeated freezing and thawing for 3 to 4 times and the cell suspension was clarified by centrifugation at $5,000 \mathrm{rpm}$ for $15 \mathrm{mins}$ at $4^{\circ} \mathrm{C}$. The supernatant was stored at $-20^{\circ} \mathrm{C}$ for confirmation of presence of virus. Reverse Transcription Polymerase Chain reaction (RT-PCR) was used for confirmation of foot and mouth disease virus in the supernatant.

\section{Results and Discussion}

Samples from cattle of different ages were collected from Savar, Joydevpur, Munshiganj, Kaliganj, Kapashia, Sirajganj, Kamrangichar, Kurigram, Rajshahi, Dinajpur, Tangail, Gaibandha, Nilphamari, Chittagong, Comilla district of Bangladesh during the year 2011- 2014. During sterility test, there was no bacterial and fungal contamination of the processed field samples.

It was found that $73.13 \%$ samples were positive for FMD virus out of 134 suspected samples, 31 samples were found positive for FMDV serotype O, 7 were positive for FMDV serotype A, 30 were positive for FMDV serotype Asia 1, 9 samples were positive for mixed infection and 21 were nontype following RT-PCR using serotype specific primer (Figure 1). 




Figure 1. Distribution of FMDV isolates in Bangladesh from 2011-2014.

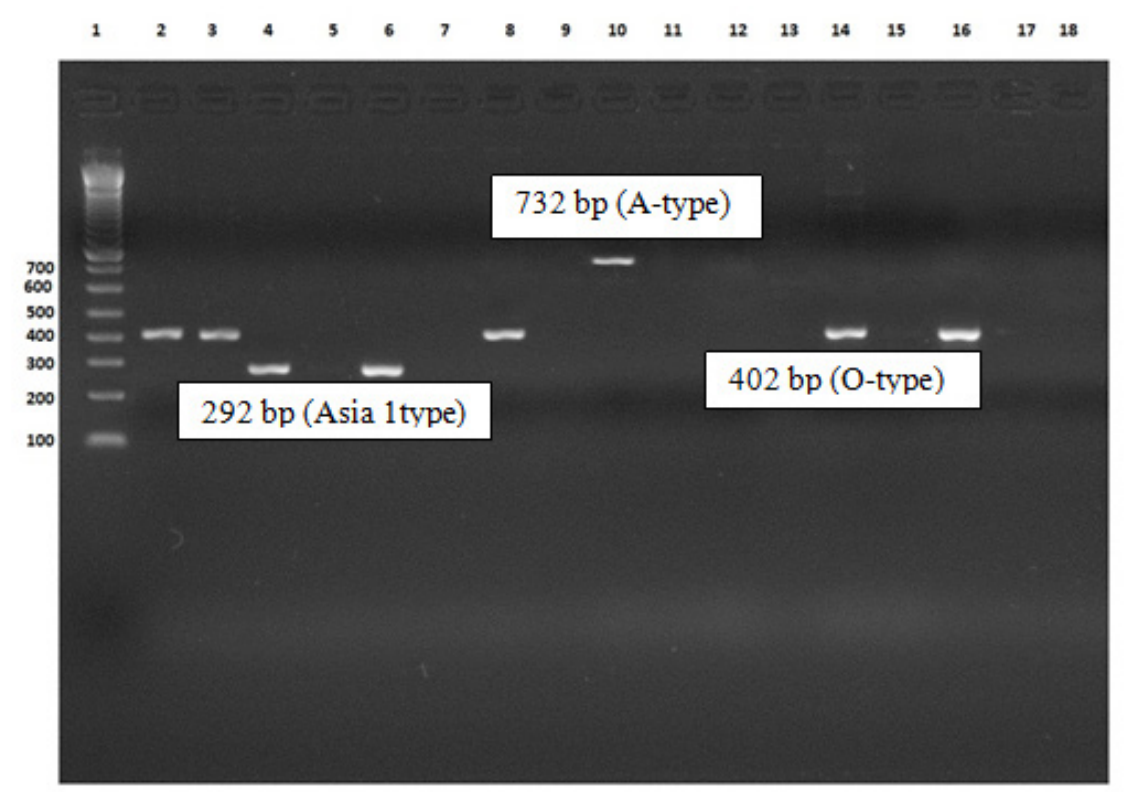

Figure 2. Electrophoresis of RT-PCR products on $2 \%$ agarose gel stained with ethidium bromide. Lane 1: 1 KB plus DNA ladder (Invitrogen, USA), lane 2, 3, 8, 14, 16: FMDV O serotype, lane 4, 5: FMDV Asia 1 serotype, lane 10: FMDV A serotype), lane 16: Positive control, lanes 17: Negative control (RNase-free water).

In conventional RT-PCR, amplification of RNA dependent RNA polymerase gene of foot and mouth disease virus yielded $402 \mathrm{bp}$ for serotype $\mathrm{O}, 732 \mathrm{bp}$ for serotype A and 292bp for serotype Asia 1 virus and no amplification in negative template control (Figure 2). Total time required to complete the RT-PCR including extraction of viral RNA is about $5 \mathrm{~h}$.

The virus inoculums (serotype $\mathrm{O}, \mathrm{A}$, Asia 1 positive) did not induce any toxic effects on the cells and cytopathic effect (CPE) could be observed on first passage onwards. Characteristic CPE appeared by $12 \mathrm{~h}$ post infection, within $48 \mathrm{~h}$ more than $60 \%$ cells died and by $72 \mathrm{~h}$ cell monolayer detached from the surface of the culture vessels. Cytopathic effects (CPE) were observed in BHK-21 cell line characterized by rounding and flattening of the cells, multinucleated giant cells formation, breaking down of the intracellular bridges and finally cell death indicated the presence of FMDV (Figure 3). Along with passage of virus CPE appeared earlier and complete CPE could be detected by $24 \mathrm{~h}$. The virus was readily adapted to BHK-21 cell line within first 3 passages. Propagation of FMDV in BHK-21 cell was confirmed by appearance of CPE comprising rounding and flattening of the cells, breaking down of the intracellular bridges and finally cell death. The findings of cell culture following infection with FMDV were similar with the findings of [12-15]. 

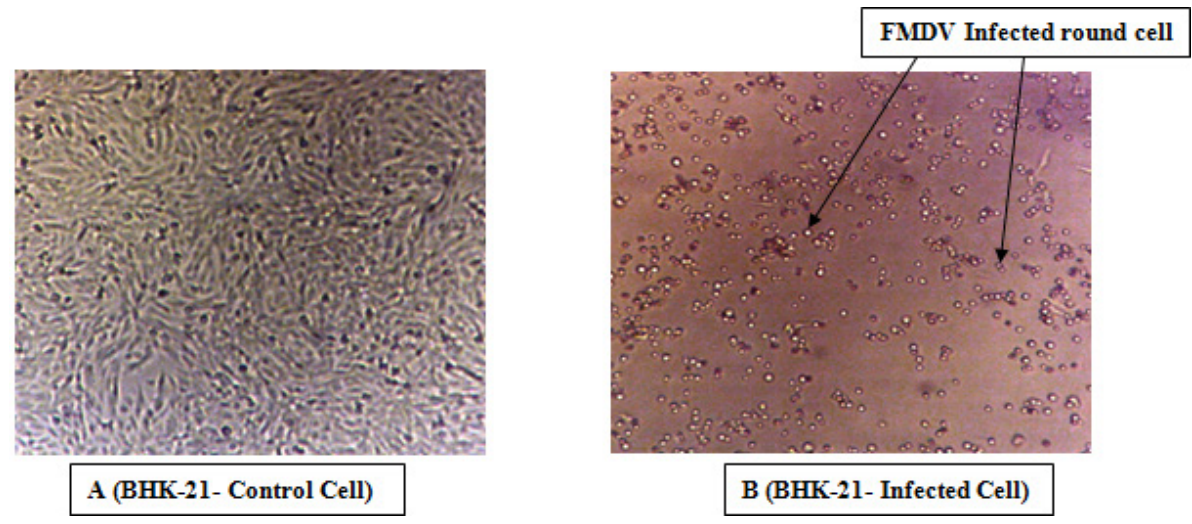

Figure 3. A) Control BHK-21 cell (Elongated shape), B) FMDV infected BHK-21 cell showing cytopathic effect (CPE) observed under 40X objective (DMS-651, China).

BHK-21 cells was often chosen as a simple in vitro model for analysis of the direct viral influences on host cell protein machinery, and routinely used for FMDV pathogenic research [16-18]. Reproduction of FMDV reached plateau period and CPE is the most obvious during $12 \mathrm{~h}$ infection. So, the time at $12 \mathrm{~h}$ post infection was selected. BHK cells vary in their susceptibility for different FMDV strains $[19,20]$. Furthermore, the ability for FMDV infection can get lost on repeated subculturing $[19,21]$.

\section{Conclusions}

Vaccination with the adapted viruses in BHK-21 cell line could still lead to an immune response that protects against infection with field isolates of FMDV strains. Further studies, including animal trials, are required to answer these questions and to prove the quality and quantity of the antigen that have been adapted in this rather circuitous manner.

\section{Acknowledgements}

The research was funded by the development project of "Research on FMD and PPR in Bangladesh" (Award no. 7080) of Ministry of Fisheries and Livestock, Bangladesh.

\section{REFERENCES}

[1] P. M. Depa, U. Dimri, M. C. Sharma and R. Tiwari. Update on epidemiology and control of foot and mouth disease - A menace to international trade and global animal enterprise. Vet. World, 5(11): 694-704, 2012.

[2] N. Longjam, R. Deb, A. K. Sarmah, T .Tayo, V. B. Awachat and V. K. Saxena. A brief review on diagnosis of foot andmouth disease of livestock: Conventional to molecular tools. Vet. Med. Int., 905768, 2011.

[3] R. Rowland. Foot and Mouth Disease. Elsevier Australia. p1, 2003.
[4] M. J. Grubman and B Baxt. Foot-and-mouth disease. Clin. Microbiol. Rev., 17: 465-493, 2004.

[5] FAO/OIE .FMD virus pools and the regional programmes. Virus Pool 2- South Asia, 2012.

[6] M. M. R. Chowdhury, M. L. Hossen, K. B Amin, K. H. M. N. H. Nazir, S. Ahmed, M .Rahman, M. F. R. Khan, M.T. Rahman, M. B. Rahman (Assessment of immune response in cattle against experimentally prepared trivalent $(\mathrm{O}, \mathrm{A}$, and Asia-1) FMD vaccine in Bangladesh. J. Adv. Vet. Anim. Res., 2(4): 475-480, 2016.

[7] OIE. Principles of Veterinary Vaccine Production. In: Manual of Diagnostic Tests and Vaccine for Terrestrial Animals. Version adopted May 2006.Chapter 1.1.7, 2009.

[8] A. E. Karim, A. S. Ebeid, M. H. B., F.K. Ibrahim, and A. M. Azab. Field application of bivalent inactivated foot and mouth disease vaccine adjuvanted by ISA 206. $4^{\text {th }}$ Science Conference, Al-Kasr 25-28 May, 2011. Benha Vet. Med. J., Special Issue (1):82-87, 2011.

[9] S .M. Reid, N. P. Ferris, G. H. Hutchings, A. R. Samuel and N. J. Knowles. Primary diagnosis of foot and-mouth disease by reverse transcription polymerase chain reaction. J. Virol. Methods, 89:167-176, 2000.

[10] W. Vangrysperre and K. D. Clercq. Rapid and sensitive polymerase chain reaction based detection and typing of foot-and-mouth disease virus in clinical samples and cell culture isolates, combined with a simultaneous differentiation with other and/or symptomatically related viruses. Arch. Virol., 141: 331-344, 1996.

[11] M. Callens, and D. K. Clercq. Differentiation of the seven serotypes of foot-and-mouth disease virus by reverse transcription polymerase chain reaction. J. Virol. Methods, 67 (1): 35-44, 1997.

[12] M. L. Hossen, S. Ahmed, M. F. R. Khan, M.T. Rahman, S. Saha, K. H. M. N. H. Nazir, M. Rahman, M. A. Islam, M. B. Rahman. Typing of Foot and Mouth Disease Virus Circulating in Bangladesh by Reverse Transcription Polymerase Chain Reaction. J. Vet. Adv. 4(12):778-785, 2014.

[13] M.A. Islam, M.M. Rahman, K.H Adam, O. Marquardt. Epidemiological implications of the molecular characterization of foot and mouth disease virus isolated between 1996 and 2000 in Bangladesh. Virus Genes, 23:203-213, 2000. 
[14] A. N. Shahiduzzaman, M. E. Haque, M. H. Rahman, M. F. Khan and M. B Rahman. Serotyping and Adaptation of Foot and Mouth Disease Virus in BHK-21 Cell Line towards the Development of Vaccine Candidate. International Journal of Vaccines, 3(2): 00060, 2016.

[15] M. A. Alam, M. Rahman, M. L. Hossen, S. Ahmed, M. S. Parvej, M. F. R. Khan, M. B. Rahman. Reverse transcription polymerase chain reaction (RT-PCR) based detection and serotyping of FMD Virus from field samples of Gazipur, Bangladesh and adaptation of the virus in BHK-21 cell. J. Adv. Vet. Anim. Res 2(3): 291-295, 2015.

[16] K. U. Anil, B. P. Sreenivasa, J. K. Mohapatra, M. Hosamani, R. Kumar, R. Venkataramanan. Sequence analysis of capsid coding region of foot-and-mouth disease virus type a vaccine strain during serial passages in BHK-21 adherent and suspension cells. Biologicals: J. Int. Assoc. Biol. Stand. 40:426-30, 2012.

[17] W. Chen, W. Yan, Q. Du, L. Fei, M. Liu, Z. Ni, Z Sheng, Z.
Zheng. RNA interference targeting VP1 inhibits foot-and-mouth disease virus replication in BHK-21 cells and suckling mice. J. Virol., 78:6900-7, 2004.

[18] X. Huang, Y .Li, H. Fang, C. Zheng. Establishment of persistent infection with foot-and-mouth disease virus in BHK-21 cells. Virol. J., 8:169, 2011.

[19] J. B. Clarke, R. E. Spier. Variation in the susceptibility of BHK populations and cloned cell lines to three strains of foot-and-mouth disease virus. Arch. Virol., 63, 1-9, 1980.

[20] J. B. Clarke, R. E. Spier. An investigation into causes of resistance of a cloned line of BHK cells to a strain of foot-and-mouth disease virus. Vet. Microbiol. 8, 259-270, 1983.

[21] A. A. Syusyukin, N. E. Tsvetkova, G. A. Kudryatseva, M. S. Syusyukin, N. I. Efimov. Cultures of foot-and-mouth disease virus in different sublines of BHK 21 cells. Veterinariya (Moscow), 51, 46-48, 1976. 